\title{
Strategi Komunikasi Pemasaran Toko @Xstyle.id pada Masa Pandemi Covid-19
}

\author{
Bayu Prasetyo Nugroho ${ }^{1}$, Nuriyati Samatan ${ }^{2}$ \\ Fakultas Ilmu Komunikasi, Universitas Gunadarma \\ bay2pras@gmail.com, nuriyatisamatan@gmail.com
}

\begin{abstract}
ABSTRAK
Toko Xstyle.id adalah salah satu pelaku bisnis fashion yang berlokasi di wilayah DKI Jakarta dimana pada saat masa pandemi covid-19 mereka tetap bertahan. Dalam hal ini diperlukan strategi komunikasi yang dapat membantu dalam memasarkan produknya sehingga Toko Xstyle.id dapat bertahan ketika menghadapi masa sulit seperti pandemi. Penelitian ini dilakukan dengan tujuan untuk memberikan gambaran mengenai strategi komunikasi pemasaran yang digunakan ketika masa pandemi covid-19 dan melihat bagaimana pemanfaatan media sosial instagram sebagai media promosi. Penelitian ini menggunakan metode deskriptif kualitatif dengan teknik pengumpulan data yang digunakan yaitu observasi, wawancara, dan dokumentasi. Informan pada penelitian ini melibatkan 1 (satu) orang sebagai key informan dan 3 (tiga) orang sebagai informan pendukung. Teori yang digunakan pada penelitian ini adalah Teori Sistem dan Teori Bauran Promosi (Promotion Mix). Hasil penelitian ini adalah bahwa terdapat elemen-elemen strategi komunikasi yang digunakan oleh Toko Xstyle.id untuk memasarkan produknya seperti Teknik Redudancy, Canalizing, Informatif, Persuasif, dan Edukatif. Selain itu, pihak toko juga memanfaatkan dengan baik keberadaan sosial media Instagram untuk dijadikan sebagai media promosi berbagai macam produknya.
\end{abstract}

Kata-kata Kunci: Covid-19, Strategi Komunikasi, Teori Sistem.

\section{Strategy Communication Marketing Store @Xstyle.id during The Pandemic Covid-19}

\begin{abstract}
Xstyle.id store is one of the fashion businesses located in DKI Jakarta area where during the covid-19 pandemic they persisted. In this case, communication strategies are needed that can help in marketing their products so that Toko Xstyle.id can survive when facing difficult times such as the pandemic. This research was conducted with the aim to provide an overview of marketing communication strategies used during the covid-19 pandemic and see how instagram social media is used as a promotional medium. This study uses qualitative descriptive method with data collection techniques used, namely observation, interview, and documentation. Informant in this study involved 1 (one) person as key informant and 3 (three) people as supporting informants. The theory used in this study is System Theory and Promotion Mix Theory. The result of this study is that there are elements of communication strategy used by Xstyle.id store to market its products such as Redudancy Techniques, Canalizing, Informative, Persuasive, and Educational. In addition, the store also makes good use of the existence of Social Media Instagram to be used as a promotional media for various products.
\end{abstract}

Keywords: Covid-19, Communication Strategy, System Theory.

\section{PENDAHULUAN}

Salah satu jejaring sosial yang telah digunakan lebih dari sekedar ajang berteman dan memamerkan baik gambar maupun video ialah media sosial berupa instagram. Selain itu, instagram pun memiliki fungsi lain sebagai media untuk memasarkan produk. Melalui jejaring sosial, pemasaran sistem online sudah berkembang menjadi sistem komunikasi yang sangat penting, hal tersebut berlaku bagi semua pihak, terutama pemasar dan tidak lupa bagi para customer. Saat ini 
keberlangsungan suatu bisnis sudah dapat ditunjang melalui pemasaran secara online.

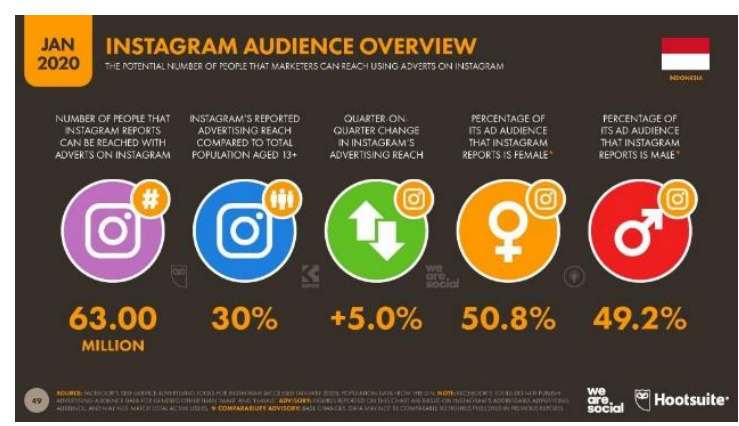

Gambar 1 Data Pengguna Instagram 2020

Sumber: Wearesocial.com

Komunikasi pemasaran ialah aktifitas yang berusaha menyebarkan informasi, mempengaruhi, dan membujuk atau megingatkan pasar sasaran terhadap perusahaan serta produknya agar bersedia menerima, membeli loyal pada produk yang dipasarkan perusahaan yang terkait. (Saladin, 2001:123)

Dengan munculnya media sosial yang mempunyai kelebihan mudah untuk diakses, hal ini memberikan dampak yang positif bagi para pengusaha dalam mempromosikan produk/jasanya. Ketersediaan perangkat yang mampu mempermudah untuk melakukan promosi produk hanya dengan cara mengunggah foto / video dengan memberikan deskripsi mengenai produk yang akan kita pasarkan. Adanya konsep yang unik serta modern, instagram dijadikan sebagai alternatif yang menjanjikan bagi para pemasar untuk menyampaikan pesan mengenai produk yang akan mereka jual.

Perkembangan dunia bisnis saat ini sudah bervariasi, beragam bentuk kreasi serta inovasi terbaru muncul ke permukaan sebagai akibat dari adanya perkembangan zaman yang semakin modern. Salah satu dari sekian inovasi yang berkembang pesat dikalangan masyarakat Indonesia adalah bisnis dibidang fashion. Dengan begitu, para pelaku bisnis ini harus mempunyai keunikan, kreatifitas, inovasi, dan ciri khas tersendiri.

Pemerintah Negara Indonesia membuat kebijakan karantina mandiri atau lockdown mulai 20 maret 2020. Dalam mekanisme pelaksanaan lockdown, terdapat instruksi secara tegas yang mengharuskan seluruh masyarakat untuk tetap berada di rumahnya masing-masing. Kebijakan lockdown ini dianggap banyak masyarakat akan mematikan sektor ekonomi di Indonesia. Oleh karena itu, pada tanggal 10 April 2020 Presiden Jokowi yang dimuat dalam wesbite kompas resmi mengganti kebijakan lockdown menjadi PSBB (Pembatasan Sosial Berskala Besar) atau social distancing. Diantaranya dengan memberikan kebijakan membatasi aktivitas keluar rumah, kegiatan pendidikan dirumahkan, bekerja dari rumah (work from home), bahkan kegiatan beribadah pun juga dirumahkan.

Dampak dari dimulainya kebijakan seperti lockdown, PSBB, dan social distancing karena pandemi Covid-19 mengakibatkan para pengusaha dan masyarakat lainnya menanggapi bahwa hal demikian dapat membuat sejumlah sektor industri dan mata pencaharian menjadi tersendat. Hal tersebut tentu sangat memberikan dampak negatif bagi pelaku usaha produk pakaian khususnya "Xstyle.id" yang ada di daerah Jakarta Timur. Selama berlangsungnya masa lockdown, PSBB, dan social distancing pelaku usaha dibidang 
Jurnal PIKMA: Publikasi Media Dan Cinema, Volume 4, No. 1, September 2021, hlm 40-48

fashion tersebut harus mempunyai cara alternatif agar bisnisnya dapat terus berjalan walaupun dalam masa pandemic Covid-19, ialah dengan melakukan pemesanan pakaian dengan cara online kemudian mengantarkannya ke tempat tujuan atau bisa juga disebut dengan delivery order, dan bagi pemilik toko mempunyai kewajiban untuk mengurangi jumlah pengunjung atau bahkan tutup untuk pemesanan secara offline. Banyak diantara para pembisnis dibidang fashion yang mengalami kerugian, sebagian besar disebabkan karena kurangnya strategi komunikasi untuk memasarkan secara efektif yang digunakan untuk menarik konsumen pada masa pandemi saat ini, dengan begitu disinilah dibutuhkan strategi komunikasi pemasaran dan pemanfaatan media sosial instagram yang sehingga para pelaku bisnis usahanya dapat berjalan serta bertahan dengan baik meskipun dalam keadaan masa pandemi Covid-19. Penulis memilih toko "xstyle.id" untuk dijadikan objek penelitian, karena menurut penulis toko tersebut sudah mempunyai ciri khas tersendiri yang menjadi pembeda diantara pesaingnya. Dengan jumlah followers pada akun instagramnya sebanyak 265 ribu pengikut.

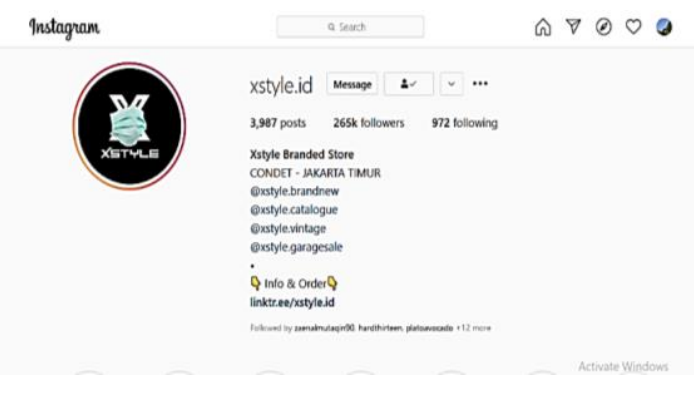

\section{Gambar 2 Tampilan Toko Xstyle.id}

Sumber : Instagram Xstyle.id

Pada masa sebelum pandemi Covid-19, diberlakukannya lockdown, PSBB, dan social distancing, toko "xstyle.id" selalu ramai dikunjungi oleh pembeli baik dari sekitar Jakarta maupun luar daerah, karena pengelola Xstyle.id memberikan fasilitas yang nyaman bagi para pembeli seperti fasilitas free WiFi, tersedianya tempat ganti hingga ruangan ber-AC yang semakin memanjakan para pembelinya. Hal inilah yang memotivasi penulis untuk mengkaji bagaimana strategi komunikasi pemasaran dan pemanfaatan media sosial instagram yang diterapkan oleh pemilik toko "xstyle.id" agar bisnisnya dapat berjalan dan bertahan ketika sedang berada pada masa Covid-19.

\section{METODOLOGI}

Pendekatan yang dipakai dalam penelitian kali ini ialah pendekatan kualitatif, adalah sebuah proses penelitian berdasarkan pada metodologi yang menganalisis suatu fenomena sosial dan masalah manusia. Menurut (Mulyana, 2008:5) penelitian kualitatif merupakan penelitian yang bersifat interpretif (menggunakan penafsiran) yang melibatkan beragam metode, dalam menelaah masalah penelitiannya. Beberapa ilmuwan menerjemahkan penelitian kualitatif deskriptif (tanpa angka-angka), tanpa usaha untuk membangun proposisi, model, atau teori (secara induktif) berdasarkan data yang didapatkan di lapangan.

Penelitian ini menggunakan Paradigma Konstruktivisme. Paradigma Konstruktivisme sosial meneguhkan asumsi bahwa masing-masing individu selalu berupaya memahami dunia dimana mereka hidup serta bekerja. Dalam pengembangan 
Jurnal PIKMA: Publikasi Media Dan Cinema, Volume 4, No. 1, September 2021, hlm 40-48

makna-makna subjektif atas berbagai pengalaman mereka, makna-makna diarahkan kepada objekobjek atau benda-benda tertentu (Samatan, 2017:135).

Subjek penelitian ini adalah seorang pemilik usaha dari Toko @Xstyle.id dan beberapa admin yang bekerja pada toko tersebut, sementara objek penelitian ini adalah Instagram yang digunakan oleh pihak Toko @Xstyle.id.

Sumber data yang akan digunakan dalam penelitian ini adalah data primer dan sekunder. Data primer yang berhasil didapatkan pada penelitian ini merupakan hasil dari beberapa teknik pengumpulan data yang digunakan seperti di antaranya observasi, wawancara, dan dokumentasi. Sementara untuk pengumpulan data sekunder diperoleh melalui berbagai sumber yang telah ada seperti buku, jurnal, artikel dan website/internet yang berkaitan dengan penelitian.

Informan dalam penelitian ini diantaranya Bang Zaenal (31 tahun) selaku owner, Ka Hanilah (19 tahun) selaku admin toko, Ka Sulistya (19 tahun) selaku admin brandnew, dan Ka Siti (22 tahun) selaku admin catalogue. Dimana 1 informan menjadi key informan berdasarkan kriteria yang telah ditentukan. Kemudian 3 informan pendukung lainnya. Wawancara dengan key informan dilakukan secara online pada tanggal 13 April 2021 melalui video call dan wawancara kedua dilakukan pada tanggal 12 April 2021 berada di wilayah Condet Jakarta Timur tepatnya pada Toko Xstyle.id.

Dalam penelitian ini teknik analisis data yang digunakan adalah (Creswell, 2012: 274-275), mendeskripsikan bahwa analisis data merupakan proses kelanjutan yang membutuhkan seleksi terus menerus terhadap data, mengajukan pertanyaanpertanyaan analisis, dan menulis catatan singkat sepanjang penelitian.

\section{HASIL DAN PEMBAHASAN}

Berdasarkan keseluruhan data yang didapatkan melalui serangkaian proses pengumpulan data seperti observasi, wawancara dan dokumentasi bahwa banyak informasi penting yang dapat dijadikan rujukan dalam penelitian ini.

Jadi inti dari pada hasil dan pembahasan ini adalah untuk melihat elemen-elemen strategi komunikasi pemasaran yang digunakan oleh pihak toko @Xstyle.id serta bagaimana pemanfaatan media sosial instagram yang digunakan sebagai media promosi secara online.

\section{Strategi Komunikasi Pemasaran Toko Selama} Masa Pandemi Covid-19

Toko Xstyle.id mempunyai beragam strategi komunikasi yang digunakan untuk memasarkan produknya. Dari awal berdiri hingga saat ini, sudah terbilang beraneka macam cara-cara komunikasi yang digunakan sebagai bagian dari pemasaran. Berdasarkan teknik pengumpulan data secara observasi, ditemukan bahwa dalam memasarkan produknya toko Xstyle.id menggunakan 5 dari 6 teknik strategi komunikasi yang digunakan pada unggahan akun Instagramnya.

\section{Redudancy (Repetition)}

Teknik Redudancy adalah cara mempengaruhi khalayak dengan jalan mengulang-ulang pesan kepada khalayak. Berdasarkan hasil observasi 
Jurnal PIKMA: Publikasi Media Dan Cinema, Volume 4, No. 1, September 2021, hlm 40-48

ditemukan bahwa pihak toko mengulang-ulang postingan mengenai hadiah grandprize dari ramadhan bazaar sale sepeda motor yang bisa didapatkan oleh konsumen dengan cara menukarkan voucher setelah melakukan pembelian. Selain itu, pihak toko juga mengunggah beberapa postingan testimoni dari para kosumennya melalui Instagram Story mereka sebagai bentuk bagian dari apresiasi kepada para konsumennya.

\section{Canalizing}

Teknik Canalizing adalah teknik yang digunakan untuk memahami dan meneliti pengaruh kelompok terhadap individu atau khalayak. Dengan cara memenuhi nilai-nilai dan standard kelompok serta masyarakat. Berdasarkan hasil observasi ditemukan bahwa pihak Xstyle.id selalu berusaha memenuhi keinginan para followersnya baik itu dengan mereview roduk-produk terbarunya sesuai dengan kemauan para konsumennya dan juga selaku owner dari toko Xstyle.id tersebut sering memberikan jawaban lansung melalui Instagram terhadap pertanyaan-pertanyaan mengenai dunia bisnis untuk para pemula.

\section{Informatif}

Teknik Informatif adalah suatu bentuk isi pesan yang bertujuan mempengaruhi khalayak dengna jalan memberikan penerangan. Berdasarkan hasil observasi ditemukan bahwa pihak toko mengunggah postingan yang berisikan penjelasan informasi mengenai akan diadakannya Bazaar Ramadhan Sale. Kemudian pihak toko Xstyle.id juga memberikan beragam informasi mengenai perilisan produk melalui website milik mereka serta informasi mengenai detail produk yang akan dipasarkan.

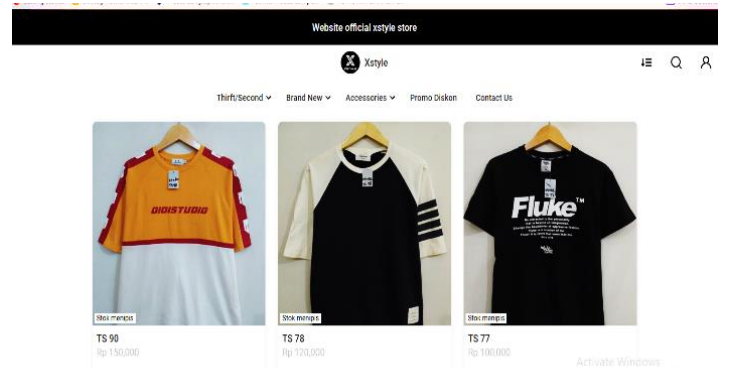

\section{Gambar 3 Tampilan Website Xstyle.id} Sumber: Website Xstyle.id

\section{Persuasif}

Teknik Persuasif adalah mempengaruhi khalayak dengan jalan membujuk. Berdasarkan hasil observasi ditemukan bahwa pihak toko Xstyle.id menggunakan strategi komunikasi persuasif untuk membujuk para konsumennya dengan cara memberikan diskon melalui garage sale agar menarik minat beli para followersnya serta adanya grandprize sepeda motor yang akan diundi pada akhir bulan ramadhan. Selain itu juga pihak toko mengunggah postingan produknya dengan pesan membujuk yang secara tidak lansung seperti "Topi best of the best nya nih, udah ganteng baru keluar dari salon" ada juga "jangan geser kesamping, bahaya ntar ada yang suka".

\section{Edukatif}

Teknik Edukatif adalah salah satu usaha mempengaruhi khalayak dari sautu pernyataan dalam bentuk pesan mendidik. Berdasarkan hasil observasi ditemukan bahwa pihak Xstyle.id menggunakan teknik strategi komunikasi edukatif ini ketika mengunggah postingan yang berisikan pesan edukasi kepada followersnya untuk tetap selalu mematuhi protokol kesehatan ketika mereka datang langsung ke toko. Kemudian strategi 
Jurnal PIKMA: Publikasi Media Dan Cinema, Volume 4, No. 1, September 2021, hlm 40-48

komunikasi eduaktif lainnya adalah pihak toko mengunggah beberapa postingan video yang berisikan pesan motivasi bagi para calon pelaku usaha agar selalu tetap konsisten.

\section{Pemanfaatan Media Sosial Instagram Sebagai Media Promosi Toko Xstyle.id}

Toko Xstyle.id sudah sangat aktif menggunakan media sosial Instagram sebagai media yang digunakan untuk mempromosikan produknya terutama ketika pada masa pandemi covid-19 saat ini. Hal tersebut sesuai dengan target mereka yaitu anak muda dan diperjelas oleh pernyataan informan kunci selaku owner dari toko Xstyle.id

"Jadi untuk Instagram itu memang banyak peminatnya di Indonesia terutama anak muda yah, karena sesuai dengan target market saya eee... target marketnya di usia 15 sampai 30 tahun dan itu kebanyakan di Instagram gitu. Eee ... sebenernya di Facebook juga bagus cuman lebih ke eee... usianya yang lebih dewasa gitu lebih tua gitu, jaid menurut saya paling ideal itu untuk anak muda di Instagram”(Bang Zaenal, 13 April 2021)

Hasil wawancara terbukti bahwa pihak toko Xstyle.id memanfaatkan peluang yang ada, dengan melihat pasar anak muda yang sangat besar. Sehingga pada kesempatan yang bersamaan mereka sangat aktif menggunakan Instagram sebagai media promosi berbagai macam bentuk produknya. Selain itu, dengan keberadaan Instagram ini toko Xstyle.id mengalami peningkatan penjualan secara online terutama ketika masa pandemi covid-19 seperti sekarang ini.

"Untuk peningkatan pastinya ada peningkatan, karena kia bisa menjangkau lebih banyak lagi, lebih luas lagi gitu yah ... jadi ordernya bukan hanya sekitaran orang
Jakarta aja, tapi lebih ke seluruh Indonesia bisa dijangkau dengan Instagram. Eee ... lebih meningkatlah dengan adanya Instagram” (Bang Zaenal, 13 April 2021)

Hasil wawancara dengan owner Xstyle.id terbukti bahwa benar media sosial Instagram sangat membantu dikala masa pandemi seperti saat ini, terbukti dengan adanya peningkatan penjualan secara online dari toko Xstyle.id itu sendiri karena pasar yang dijangkau bisa lebih luas dari pada melalui toko offline.

\section{Analisis Melalui Teori Sistem}

Dikutip dari buku Encyclopedia of Communication Theory karya Stephen W. Littlejohn dan Karen A. Foss Teori sistem merupakan gagasan yang diterapkan secara luas ke beberapa hal, seperti fenomena alam, sosial, dan pribadi, temasuk kognisi, hubungan interpersonal, kelompok sosial, organisasi, serta lembaga, organisme biologis, dan lingkungan alam (Littlejohn \& Karen, 2009:950).

Semua sistem mempunyai empat aspek, yaitu objek, atribut, hubungan internal, dan lingkungan. Atribut merupakan karakteristik dari objek-objek ini dan sistem secara keseluruhan. Hubungan internal terbangun dari pola interaksi sesama objek, kemudian lingkungan ialah sistem pengaruh yang bertindak atau berdampak pada sistem dalam berbagai macam cara, suatu keluarga, contohnya, terdiri dari individu-individu (objek) dengan beragam tingkat pengetahuan, keprbadian, pengalaman, dan seringkali mempunyai DNA (atibut) yang saling berbagi yang berkomunikasi satu sama lain secara berpola (hubungan internal). 
Jurnal PIKMA: Publikasi Media Dan Cinema, Volume 4, No. 1, September 2021, hlm 40-48

Kemudian keluarga tersebut berada dalam lingkup masyarakat yang lebih luas.

Dari penjelasan mengenai teori sistem tersebut, peneliti menemukan 4 unsur aspek yang ada pada Toko Xstyle.id yaitu aspek objek, atribut, hubungan internal dan lingkungan.

Hasil penelitian yang dilakukan pada Toko Xstyle.id adalah terdapat aspek Objek yang digambarkan dengan karyawan-karyawan yang bekerja pada Toko Xstyle.id. Data yang peneliti dapat menjelaskan bahwa karyawan yang bekerja pada Toko Xstyle.id sampai saat ini berjumlah 6 orang.

Selanjutnya, ditemukannya aspek Atribut yang menggambarkan karakteristik yang terjalin diantara sesama objek. Data yang peneliti dapat menjelaskan bahwa karakteristik dari objek yang digambarkan sebagai karyawan komunikasinya berjalan dengan baik secara kekeluargaan. Tidak mengenal adanya istilah atasan bawahan, melainkan pada Toko Xstyle.id ini mereka sangat menjunjun tinggi nilai kekeluargaan.

Kemudian, ditemukannya aspek hubungan internal yang menggambarkan pola interaksi yang terjadi antar sesama objek. Data yang peneliti dapat menjelaskan bahwa hubungan yang terjalin antara owner dan karyawan sangat baik, dikarenakan pegawai yang bekerja di Toko Xstyle.id tersebut merupakan orang-orang terdekat yang saling mengenal satu sama lain, dari situ terciptalah hubungan komunikasi yang dekat.

Terakhir, ditemukannya aspek Linkungan yang menggambarkan sistem pengaruh yang bertindak atau berdampak pada sistem. Data yang peneliti dapat menjelaskan bahwa Toko Xstyle.id ini sendiri sudah melakukan tindakan yang mempunyai pengaruh positif bagi masyarakat. Seperti memberikan bantuan donasi untuk bencana alam yang ditujukan untuk masyarakat luas serta untuk masyarakat sekitar, pihak Toko Xstyle.id turut memberikan bantuan dan berusaha untuk memperdayakan orang sekitarnya dengan cara memperkejakannya baik itu sebagai tukang parkir ataupun penertiban lalu lintas untuk akses jalan.

\section{Analisis Melalui Bauran Promosi}

Bauran pemasaran terdiri atas empat kelompok variabel yang disebut "empat P" yakni: Product, Price, Place, Promotion. Dari 4 unsur tersebut, peneliti telah melakukan analisis dan didapatkannya:

\section{Product}

Toko Xstye.id menjual berbagai macam produk fashion, lengkap dari bagian atas kepala sampai dengan ujung kaki. Dengan didominasi oleh produk laki-laki, seperti topi, baju, hoodie, sweater, celana, sepatu dan aksesoris lainnya. Selain itu mereka juga mempunyai produk unggulan untuk dipasarkan yaitu untuk produk unggulan bawhan ada celana jenis chino, serta produk unggulan atasan yaitu sweater, crewneck dan hoodie. Dengan demikian memperjelas bahwa produk yang dijual oleh Toko Xstyle.id dapat dikatakan lengkap.

\section{Price}

Dalam menjualkan produknya Toko Xstyle.id memberikan harga yang terbilang sangat ekonomis, yakni harga berkisar mulai dari 50 ribu sampai 500 ribu dan dengan harga pasti sebesar 150 
Jurnal PIKMA: Publikasi Media Dan Cinema, Volume 4, No. 1, September 2021, hlm 40-48

ribu. Penentuan harga tersebut berdasarkan dari survei yang sudah dilakukan oleh owner toko tersebut, sehingga harga dapat bersaing dan mempunyai nilai jual yang lebih bagus.

\section{Place}

Pemilihan tempat yang dijadikan sebagai lokasi Toko Xstyle.id dapat dikatakan sangat strategis, karena berada pada kawasan padat penduduk, selain itu akses menuju toko yang mudah untuk dijangkau, karena letaknya berada di wilayah Condet Jakara Timur yang padat penduduk serta akses menuju toko sangat mudah. Selain itu, fasilitas yang terdapat pada Toko Xstyle.id ini membuat nyaman bagi para konsumen yang berbelanja lansung di toko mereka. Seperti keberadaan tempat parkir beserta penjaganya yang membuat pembeli tidak perlu khawatir lagi, kemudian ruangan toko yang berAC untuk para pembeli yang sudah jauh jauh datang sehingga ketika berbelanja merasa nyaman. Selanjutnya, disediakan ruangan fitting room yang keberadaannya sangat berguna untuk para pembeli agar produk yang dibeli dapat dipastikan sesuai dengan pemakainya.

\section{Promotion}

Pihak Toko Xstyle.id dalam menarik minat konsumen menggunakan promosi baik itu online dan offline, untuk promosinya sendiri itu pihak toko menyiadakan kupon undian berhadiah sepeda motor setiap pembelian diatas 100 ribu, selain itu adanya diskon apabila belanja diatas 1 juta. Untuk onlinenya sendiri itu terdapat bonus free ongkir sehingga para pembeli tidak terbebani dengan biaya tambahan.

\section{KESIMPULAN}

Berdasarkan data yang sudah peneliti dapatkan, terbukti bahwa pihak Toko @Xstyle.id dalam memasarkan produknya menggunakan 5 Strategi Komunikasi Pemasaran seperti Teknik Redudancy (Repetition) yang dimana pihak @Xstyle.id mengulang-ulang pesan baik itu untuk menarik minat pembeli ataupun bentuk apresiasi bagi para konsumennya. Kemudian Teknik Canalizing, yang dimana pihak mengaplikasikan teknik dengan bentuk pemenuhan terhadap keinginan-keinginan pada konsumennya, sehingga adanya kepuasan yang timbul dari pemenuhan nilai tersebut. Selanjutnya Teknik Informatif, dimana pihak toko berusaha untuk memberikan informasi kepada pada followersnya mengenai berbagai macam produk yang akan mereka posting baik itu di website toko ataupun Instagram. Selain itu, terdapat juga Teknik Persuasif yang dimana pihak toko dalam membujuk para konsumennya dengan mengadakan grandprize berupa sepeda motor yang bisa didapat melalui undian dengan voucher yang diterima dari transaksi pembelian. Dan yang terakhir adalah Teknik Edukatif, yang dimana pada masa pandemi seperti sekarang ini, pihak toko turut memberikan edukasi tentang protokol kesehatan yang harus ditaati bagi para konsumennya ketika hendak datang ke toko dan bentuk edukasi lainnya berupa motivasi-motivasi untuk pada calon pelaku usaha.

Dalam pemanfaatan media sosial Instagram, pihak toko dapat mengaplikasikan media sosial Instagram dengan baik. Hal demikian dapat 
Jurnal PIKMA: Publikasi Media Dan Cinema, Volume 4, No. 1, September 2021, hlm 40-48

dibuktikan dengan meningkatnya penjualan online akibat dari promosi-promosi yang dilakukan oleh pihakToko@Xstyle.id melalui media sosial Instagram. Dengan ciri khas mereka, yang selalu mengadakan review langsung mengenai produknya, sehingga para konsumen tidak merasa adanya penipuan dari produk yang dipasarkan.

Saran yang peneliti berikan adalah agar Kepada pihak Toko @Xstyle.id kedepannya diharapkan mampu menggunakan strategi-strategi yang lebih fresh, sehingga memungkinkan untuk dapat menarik minat pasar yang jauh lebih luas lagi. Kemudian kedepannya mencari-cari inovasi yang baru dalam hal promosi produknya melalui media sosial Instagram.

\section{DAFTAR PUSTAKA}

Akhmad Rifqi. 2015. Strategi Komunikasi Pemasaran Buku Dalam Meningkatkan Penjualan Melalui Media Sosial Instagram (Studi Deskriptif Pada Pendiri @Tausyiahku). Universitas Negeri Sunan Kalijaga Yogyakarta.

Creswell, J. W. 2012. Research Design Pendekatan Kualitatif, Kuantitatif, dan Mixed. Yogyakarta: Pustaka Belajar.

Ihsanuddin., Hakim, R N. Pidato lengkap Jokowi, dari PSBB, listrik gratis, hingga keringanan kredit. Retrieved June, 12, 2021, from Kompas.com website:

https://nasional.kompas.com/read/2020/03/31/162 71751/pidato-lengkap-jokowi-dari-psbb-listrikgratis-hingga-keringanan-kredit?page=all

Littlejohn W. Stephen dan Karen A. Foss. 2009. Ecyclopedia of Communication Theory. USA: Rolf A. Janke.

Mulyana, Deddy. 2008. Ilmu Komunikasi: Suatu Pengantar. Bandung: Remaja Rosdakarya.

Saladin, Djaslim. 2001. Manajemen Pemasaran, Analisis, Perencanaan, Pelaksanaan, dan Pengendalian. Bandung: Lindakarya.
Samatan, Nuriyati. 2017. Riset Komunikasi 1. Jakarta: Gunadarma.

Trias Aprilya. 2017. Strategi Komunikasi Pemasaran Nadyafashop melalui Instagram Dalam Meningkatkan Kepercayaan Customer Di Samarinda. Universitas Mulawarman. 